\title{
Accounting Standardisation, Systemic Fissure and Fraud: The Concatenated Causal Nexus Neglected
}

\author{
By Carlos Eduardo Gonçalves de Godoi* \& Samir Kilson Diast
}

The process of convergence between the national accounting standardisation and the International Accounting Standards Board, in order to break with the rules-based approach and to house the leading edge of rule by principles in accounting, alludes to a credible and constructive evolutionary journey from the purely and strictly accounting point of view. However, there are compelling reasons that warrant caution in making a favourable and categorical opinion on the transposition of accounting standardisation's approach, since the scientific nature of accounting is incapable in itself of providing a more accurate argument about the contrast between advantages, and especially the drawbacks, of scriptural rule-making and principles regarding the generation of systemic fissures that create favourable conditions for the practice of corruption through fraud in accounting entries. This paper promotes a brief review of the benefits, costs and conjuncture of opportunities and risks arising from the adoption of both systems, resulting in a critical analysis that encourages the search for conciliatory and innovative alternatives.

Keywords: Accountability: Corruption; Fraud; Standardisation.

\section{Introduction}

In order to unify and improve the financial disclosure and the operation of the market with a high standard of quality, the beginning of the century was marked by a movement of convergence of accounting standards, abandoning the traditional model based on detailed rules for the various economic events accountable with the aim to produce comparability of information with the lowest content of subjectivity, to adopt an account standard based on principles, also known as International Financial Reporting Standards (IFRS), and edited by the International Accounting Standards Board (IASB), which permits the accountant to interpretation at the time of recognising, classifying and disclosing economic events, so that it most appropriately reflects the economic essence of the operation according to its professional judgment.

However, aside from the predominant adoption of the international standardbased accounting standard set forth in IFRS, the US system has adopted a goalbased normative model that, roughly speaking, is a hybrid construction of the

\footnotetext{
*Researcher, Pontifical Catholic University of Minas Gerais, Belo Horizonte, Minas Gerais, Brazil. Email: carlosgodoi@me.com.

${ }^{\ddagger}$ Researcher, Pontifícal Catholic University of Minas Gerais, Belo Horizonte, Minas Gerais, Brazil. Email: skilson19@yahoo.com.br.
} 
two standards cited above, which is highlighted by its focus on overcoming gaps in both accounting standards.

In this vein, the central issue of this paper is devoted to analysing how the weaknesses of these accounting normative systems can influence the practice of corrupt activities through accounting fraud. Thus, the systemic fissures of these models become another important aspect of the fight against corruption, as important as other matters of order, such as money laundering, strict liability of the legal person, international legal cooperation, asset recovery, et cetera.

The objective of the present study is justified by the importance of accounting activities as a support and concealment of corrupt activities and its incipient attention by the academy and public anti-corruption policies. The excessive focus on the normative and social aspects of corruption, in an exclusionary perspective regarding accounting, results in an embryonic production of scientific works and legal and regulatory norms dedicated to the fight against accounting fraud under a conjunctural view of corruption, that the present the article is proposed to reflect.

Considering that the research problem of this work is the verification of how the normative gaps of accounting systems create opportunities or discourage accounting fraud, which in turn support corrupt activities, this paper seeks to answer the following questions: How do systems accounting policies influence the practice of accounting fraud? What are the main characteristics and differences between accounting standardisation models? Which model of accounting standardisation presents fewer risks for the accounting fraud exercise? In what way can adequate accounting normative system influence individual decisions by corrupt practice?

This production contributes to the discussion of this subject in the first chapter, based on the examination of normative accounting models based on rules, principles and objectives, delimiting its main aspects and employing a comparative analysis with the critical support of doctrinal arguments. Next, it is verified how the fissures of accounting normalisation systems influence the practice of corruption, observing both its technical-accounting aspect and its psycho-social aspect, in order to satisfactorily reach the solution of the research problem.

The methodological structure of the research adopts a qualitative approach to the collection of data and information, which, according to Hartmut Günter ${ }^{1}$, is the most appropriate approach for the discovery and construction of theories based on a textual search, whose data collection, in the different techniques are interpreted hermeneutically. The adoption of qualitative research is justified because it is a propitious approach to reach an understanding about the phenomenon under study through explanations or understandings of the relations between variables.

Moreover, the present research still adopts the exploratory level about the object of study, since its main purpose is the clarification and modification of concepts and ideas, providing an approximate general view about a certain

${ }^{1}$ Günter (2006) at 202. 
fact $^{2}$. This in this case is the verification of the literature regarding standardisation and accounting fraud to verify if there is a conflict between accounting normative models and the correlation with fraud.

According to Antonio Carlos $\mathrm{Gil}^{3}$, it is developed from material that has already been produced and is mainly composed of, from scientific books and articles, with the main advantage being that it allows the coverage of a much broader range of phenomena than could be investigated directly by other means.

\section{Accounting Normalisation Based on Rules and Principles and The Advent of The Objective-based Approach}

There are, within accounting science, a plurality of divergent conceptions about the purposes of accounting, whether through a more scientific view or a more pragmatic perspective, as can be seen by the contrast between Hendriksen \& Van Breda conception in a restricted scope to the calculation and the presentation of the net profit resulting from a set of rules of accomplishment and $\mathrm{tie}^{4}$, and the thought of Howard Noble ${ }^{5}$, centred in the presentation of information that reflects the relation between the commercial operations and their impact in the property.

Brazilian doctrine is replete with other theoretical contributions with the same purpose of engendering efforts to bring light to accounting thinking, as can be seen in the reading of Domingos D'Amore \& Adaucto Castro ${ }^{6}$, Silvio Crepaldi $^{7}$ and Hilario Franco ${ }^{8}$. However, in view of so many theoretical propositions regarding the purposes of accounting, the Federal Accounting Council (CFC), in its Resolution 774/1994, presented a pertinent premise that illustrates the initial thinking of the present study. According to the pronouncement contained in said normative instrument, there is a tangle of specific objectives that are not lucky enough to be primordial to the definition of a science, the objective of Accounting being the correct presentation of the equity and the apprehension and analysis of the causes of their mutations.

In this way, the crucial role of Accounting for its various users, reflected in the accounting statements that affect business management, market development and financial system governance, is undeniable. In the light of its role in guiding the way in which the operators reflect the economic essence of the operations, it is important to note the prominence of the studies that favour the normative approach ${ }^{9}$.

The academy shares a reasonable consensus regarding the need to establish a normative standard that will serve as a reference for professionals, predicting

\footnotetext{
${ }^{2}$ Gil (2008) at 27.

${ }^{3}$ Gil (2008).

${ }^{4}$ Hendriksen \& Van Breda (1999).

${ }^{5}$ Noble (1956).

${ }^{6}$ D'Amore \& Castro (1976).

${ }^{7}$ Crepaldi (1995).

${ }^{8}$ Franco (1997).

${ }^{9}$ Kothari (2001).
} 
the failures of the marketing mechanisms, as well as their contrariness to social interests. The divergence lies in establishing the appropriate model to be adopted for the better attainment of this end, and it is therefore important to briefly consider the concept of true and fair view.

The concept of true and fair view establishes the prevalence of a true and fair view of the real economic and financial situation of the business, as well as its results, prevailing, above all, legal and regulatory ${ }^{10}$. In objective terms, this premise confers a higher degree of subjectivity to accounting operations and greater autonomy to its operators, so that in situations where the professional understands that the rules corrupt the economic essence of certain records and disclosures, the concept of true and fair view is prioritisd to the detriment of normative forecasts.

Despite the attempt to guarantee security to grant the highest degree of freedom to choose the accounting criterion through the necessary referral to the independent auditors, the objective of this concept is very optimistic and carries a reasonable weight regarding its supremacy over the legal requirements and accounting principles, being plausible the instrumentalisation of the expression by managers so that they could do what suited them ${ }^{11}$.

The rules-based Generally Accepted Accounting Principles (US-GAAP) model adopted by the United States reflects the aforementioned positioning, repelling the concept of true and fair view in favour of the objectivity of accounting valuations, restricting the auditor to a qualitative analysis of financial reports and strict observance of detailed accounting rules that translate customs, the basis of the Common Law system in force in that country ${ }^{12}$.

Prior to the approximation of the normative accounting model based on rules, in the best methodological interest, it will be discussed about the accounting system based on principles, in which is the prevalence of the essence on the form. Principle-based accounting systems have as their basic assumption the direction of accounting standards by an open-ended conceptual framework that suppresses specific criteria for the evaluation of particular situations and then entrusts it to the value judgment of accounting professionals ${ }^{13}$.

In spite of the definition of the normative model based on the principlebased approach, this system is endowed with characteristics that define it in relation to the system based on rules, that is, the establishment of norms that only have basic guidelines, the influence of the concept of true and fair view, the search for the best expression of economic and financial reality, procedures with a high subjectivity burden, high evidence of transactions and events, the prevalence of the essence of the transaction or economic event over the legal form, judgment of the accounting professional and greater degree of autonomy for presenting information ${ }^{14}$.

\footnotetext{
${ }^{10}$ Dantas, Rodrigues, Niyama \& Mendes (2010) at 7.

${ }^{11}$ Jreige (1998) at 1.

${ }^{12}$ Paulo, Carvalho \& Girão (2014).

${ }^{13}$ Schiper (2003).

${ }^{14}$ Paulo, Carvalho \& Girão (2014).
} 
Brazil has initiated the first efforts to harmonise with the international accounting standards contained in the International Financial Reporting Standards (IFRS), published by the International Accounting Standards Board (IASB), in the last two decades, with special attention to the edition of Circular 3068 of the Central Bank of Brazil, the creation of the Accounting Pronouncements Committee, the issuance of CVM Instruction 457/2007 and the promulgation of Law 11,638/2007. This process of convergence with international accounting standards has given the Brazilian accounting model a progressive nature, with the proper proviso that it is a position not yet pacified in doctrine, although the Accounting Pronouncements Committee, which studies, prepares and makes technical pronouncements, has given an opinion in defines of the current principle-based standard.

In other mats, there is a rule-based accounting system, which pursues a completely different approach, with detailed norms that provide specific methods for the treatment of all problems and expected situations ${ }^{15}$. The rules-based accounting model has as its characteristics the condition for greater comparability of information - given that there are controversies in the doctrine - detailed rules that reflect accounting procedures, pragmatic observance of normative terms, high degree of objectivity, evidence of economic reality ${ }^{16}$. In addition, it is important to note that, in the case of transactions, the legal requirements are not met.

US-GAAP is the US regulatory accounting system based on a mitigated framework of rules, with detailed implementation and interpretation guidelines coupled with a certain degree of principiology, justified by corporate scandals involving US companies Enron, WorldCom and Tyco in the early 2000s, which cast doubt on the effectiveness of the US accounting model, but that did not force the nation to completely succumb to its standards in favour of international convergence. After several attributions of guilt to the then rulebased accounting model, which by its failures allowed for financial engineering actions capable of transgressing the legal regime, the US Congress enacted the Sarbanes-Oxley Act, which in Section 108 led to the adoption of an objectivebased disclosure standard ${ }^{17}$.

The normative accounting model by objectives invokes imperfections in principles, as well as rules, based models, and ends by deconstructing both models to propose an accounting system that raises the objectives of accounting standards to the level of protagonism, which must be clearly defined and sufficiently detailed. The objective approach is believed to outweigh fraud gaps because the imposition of accounting objectives in the direction of procedures minimises the opportunities for manipulation of accounting reports, as well as avoiding exceptions because they are contrary to the essence of the standard ${ }^{18}$.

It is not relevant to the present study to discuss the normative accounting system by objectives alone, because its focus is grounded on evaluating the

\footnotetext{
${ }^{15}$ Benston, Bromwich \& Wagernhofer (2006).

${ }^{16}$ Paulo, Carvalho \& Girão (2014) at 26.

${ }^{17}$ Alexander \& Jermakowicz (2006).

${ }^{18}$ Paulo, Carvalho \& Girão (2014) at 28.
} 
validity of abandoning a previously widely used approach with the purpose of proposing the adoption of a new vision under the aegis of "progress". Before the reading of the divergent accounting models, it is necessary to highlight its merely expositive explanation, being primordial a critical analysis on its effects and consequences by means of a comparative approach, exposed in the following chapter, before deepening the discussion on its consonance.

\section{Critical Examination of Accounting Models based on Principles and Rules}

Preliminarily to the examination of normative accounting systems, it becomes relevant to clarify a fundamental assumption for the current under analysis, without which it is impossible to reach the objectives of the present study. Accounting standards cannot be applied in a completely consistent way, whether based on principles or rules, because there will always be some limitation that will make it possible to deviate in the application and effectiveness of the rules. Thus, we advocate the inconsistency of certain aspects and the existence of other elements that can be used in both approaches ${ }^{19}$.

With regard to the debate about the inconsistency, which ravages the reforms carried out by the main accounting standards, two important approaches must be highlighted: the inconsistency with the content of accounting standards issued by accounting regulatory bodies and the inconsistency of the application of these standards on the factual plane $e^{20}$. It is certain that the two concepts are interlinked, so that if there is no consistency in the application of the accounting criteria, enforcement of these standards is impaired.

When the process of convergence of the Brazilian rules-based accounting system, previously based on rules, started to be adopted, several specialists, due to the influential campaign promoted by the Federal Accounting Council, listed negative factors of what they considered as "Outdated" model and extolled the benefits of the "new breakthrough" of accounting. The present production assumes the opposite, highlighting benefits and limitations of both systems, initially approaching the rule-based model and posteriori the principlebased model.

Katherine Schipper ${ }^{21}$ points to the increase of comparability as a benefit of the rule-based model, which, in short, means the decrease of divergent professional opinions due to the high degree of specificity of the rules. However, if the rule is not strictly adhered to, it is necessary to consider the existence of a false comparability which, consequently, gives equal treatment to non-similar businesses.

Another positive effect associated with the use of detailed norms, is the mitigation of the probability of biased interpretations. However, according to the authors, this same detailing of the rules opens the door to financial engineering

\footnotetext{
${ }^{19}$ Paulo, Carvalho \& Girão (2014).

${ }^{20}$ Wustemann (2010).

${ }^{21}$ Schiper (2003).
} 
arrangements that masked accounting entries in contradiction to their purposes under the veil of a superficial compliance with the rules ${ }^{22}$.

The increase of verifiability is another benefit that accompanies rule-based normative systems, because in theory, the detailed guidelines lead professionals to be guided by a knowledge base resulting from the common consensus, resulting in the reduction of divergences of a measurement. However, the degree of specificity of these rules leads to an increase in costs with specialists who interpret them safely and at the same time allows professionals with a high accounting knowledge to be hired to structure contracts in order to circumvent the rules ${ }^{23}$.

As we have seen, the rule-based accounting model has benefits and disadvantageous effects, and the same reasoning applies to the principlestructured system, so that by the following exposition the inconsistencies of both models allow us to infer that none of these formally surpasses the imperfections of the other ${ }^{24}$.

The first positive effect of the principle-based accounting normative model rests on the comparability of information, which, as in the rule's regime, has positive and negative aspects. The suppression of scope and treatment exceptions makes information more comparable, but on the other hand, this same agreement with the professionals' discretion results in the coexistence of different interpretations, causing some imprecision ${ }^{25}$.

Due to this discretion delegated to professionals before the material opening of standards, expert judgment becomes essential and, ultimately, intensifies the responsibilities of auditors and accountants, demanding greater investment in the educational system, otherwise it will make its users, as an example of investors and companies, the most impaired ${ }^{26}$.

The intensification of auditors 'and accountants' responsibilities due to the increase in the subjectivity of accounting standards, while contributing to the quality of professional judgments, also leads to the resistance of auditors who fear pressure from opportunistic demands from corrupt managers, increasing the costs of accounting activity or even discouraging it due to the risks of accountability in the civil, administrative and criminal spheres arising from corporate pressure for fraudulent postings. In addition, there is coexistence with the malicious error, the culpable failures arising from the increase of imprecision of the norms and that lead to the objective responsibility of the companies, thus raising the costs with the implementation of conformity programs that guarantee the effective alignment of the demonstrations with the norms accounting. In the same sense, the adoption of the principles makes accounting standards more accessible to understanding and implementation, as well as making the adjustment to the economic substance of events easier ${ }^{27}$.

\footnotetext{
${ }^{22}$ Nelson, Elliot \& Tarpley (2002).

${ }^{23}$ Nelson, Elliot \& Tarpley (2003).

${ }^{24}$ Schiper (2003).

${ }^{25}$ Schiper (2003).

${ }^{26}$ Alexander \& Jermakowicz (2006).

${ }^{27}$ Nelson, Elliott \& Tarpley (2002).
} 
In the face of all the positive and negative aspects of both of these accounting normative systems, there is no scientific study that has precisely chosen which is the best alternative, so much so that the United States has found a third alternative along with the whole clash between ${ }^{28}$. However, this whole process of reflection follows another tangent that can be summarised in a single question: would it be possible to harmoniously coexist between the elements of both normative accounting systems?

\section{The Convergence of Principles and Rules in Accounting Standardisation}

As to the possibility of harmonious coexistence between principles and rules, a priori, one can safely affirm such a thesis, as well as corroborate it by means of empirical arguments and theoretical bases. The overcoming of rulesbased norms and principles in favour of a conciliatory alternative that adds to the advantages and obliterates the disadvantages of both systems has its support in the factual plane through the US approach to accounting objectives.

The standardisation by accounting objectives consists of a kind of hybrid system, which integrates the best characteristics of the rules and principles systems under the guideline of accounting objectives, which, in turn, are determined by harmonising the interests of groups of companies, users and accounting professionals ${ }^{29}$.

According to the Venn diagramme, these three groups preserve a constant interaction marked by a conflict of interest around the accounting information, as follows:

\section{Figure 1. Venn Diagramme}

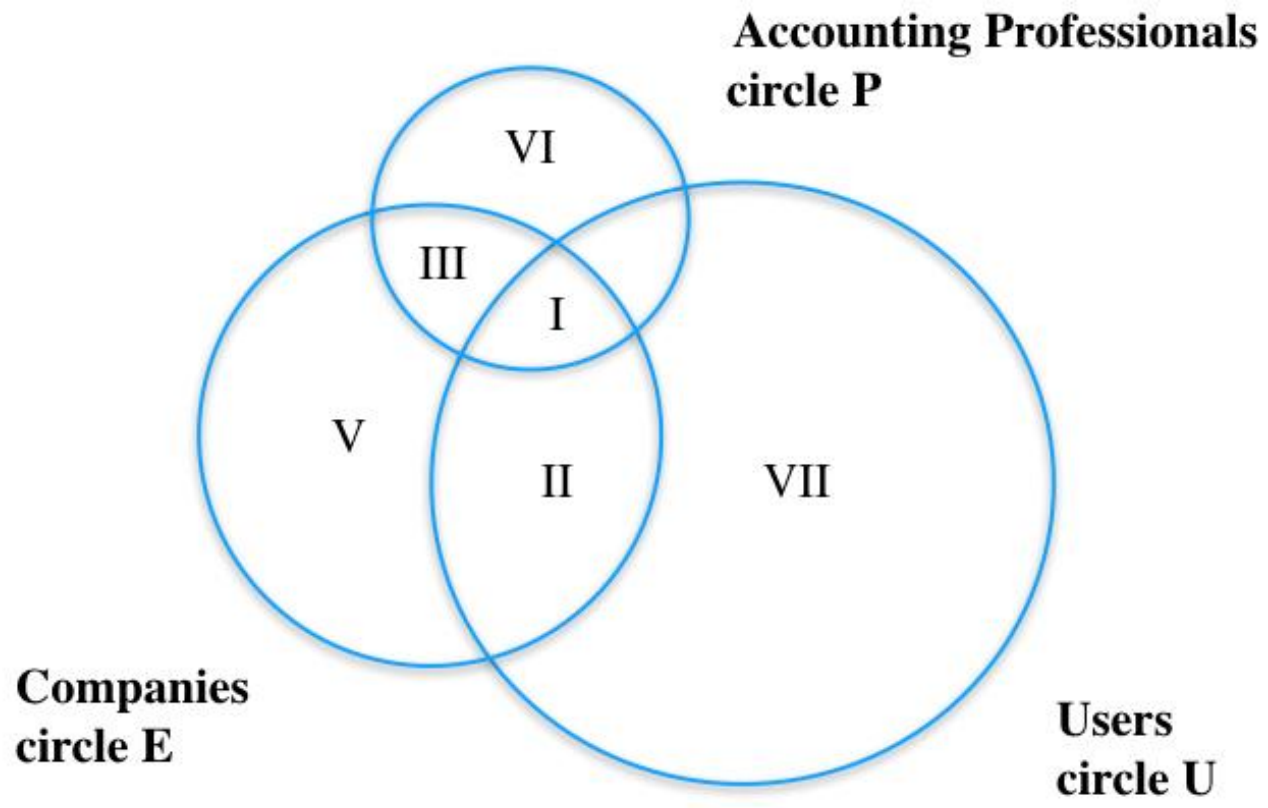

Source: R.M. Cyert \&; Y. Ijiri in Paulo, Carvalho \& Girão (2014) at 29.

\footnotetext{
${ }^{28}$ Antunes, Grecco, Formigoni \& Neto (2012).

${ }^{29}$ Paulo, Carvalho \& Girão (2014).
} 
The group of companies has an interest in the set of accounting information evidenced in the financial statements, while the users have an interest in information that is useful for economic decision making, and the group of professionals with interests focused on the production and validation capacity of the companies accounting information ${ }^{30}$.

In the middle of the conflict of interests between the three groups, expressed in the diagramme above, standardisation by objectives, aims to prioritise the interests of one of the three groups, defining them as the objectives of the accounting system. In the case of the United States, US-GAAP, following the intent of the Sarbanes-Oxley Act, privileged the financial market professionals, with particular attention to investors. The adoption of the accounting objectives is intended to simplify the rules-based rule system previously in force, which contains a considerable amount of exceptions, and "this makes new rules necessary to explain previous ones, increasing the volume of reading, more exceptions and more complexity. This is all due to principles that are not well defined" 31 .

In other words, rules-based regulation adopts a very broad coverage approach of all possible situations in the accounting process, which leads, therefore, to the issue of more rules for each new situation that arises and that was not covered previously or every time accounting facts become more complex.

In the same way, it was noted that the normalisation by principles allowed for several inaccuracies, due to the open content of the norms, generating the possibility for opportunistic interpretations and a systemic imbalance that could compromise the purposes of said norms.

Thus, the Security Exchange Commission (SEC), the US government agency that regulates compliance with securities market laws, proposed accounting standardisation by objectives because it believed that the approach contained a sufficiently detailed structure, without the exaggeration of rules and without principles so that the professionals can perform the accounting procedures in accordance with the users' instances.

In addition, it is necessary to emphasise that the present production does not aim at electing the normative accounting model based on objectives as the ideal scope to be adopted by the accounting systems. On the contrary, the objective is to recognise the ability to combine rules and principles in a single regulatory system.

Rules and principles have diverse characteristics and roles in a normative system. Basically, rules are conceived under the logic of "all or nothing", in which they are or are not fulfilled, facing strictly a question of validity, whereas the principles have degrees of concreteness that vary according to the factual and legal conditionality, and as they can coexist with antinomic principles, in a process of balancing values and interests ${ }^{32}$.

There is no ideal normative scope that contains only principles or just rules, since both balance the limitations present in its bulge, and the rules are

\footnotetext{
${ }^{30}$ Paulo, Carvalho \& Girão (2014).

${ }^{31}$ Paulo, Carvalho \& Girão (2014) at 29-30.

${ }^{32}$ Alencar (2006).
} 
necessary to regulate conduct, and the principles are like mechanism of foundation, interpretation, integration and direction of these rules ${ }^{33}$. Although such thinking has been drawn from a juridical work that has examined the dynamics of rulebased principles and rules applied to law, the general plans for such conception can be transposed into the accounting field, and its origin finds factual support from recent initiatives of the FASB to include a series of rules to its originally rules based on principles, demonstrating a tendency to become a normative system by objective, according to US-GAAP ${ }^{34}$.

Although Brazil is on the road to convergence of its accounting standards with the international standards of the IASB, its new application is not yet effective, as there is a strong influence of the legal determinations on accounting standards regarding corporations, as well as of the fiscal legislation that exerts strong lease transactions of a financial nature. The principle-based accounting model landed in Brazil rooted in a very optimistic view without the proper academic debate with the breadth and scope necessary to consider the issue of cultural impact, the lack of professional expertise and the degree of preparation of knowledge centres. On this aspect, its important note that:

The relationship of benefits and costs, opportunities and risks, advantages and disadvantages, positive and negative aspects of adopting accounting systems based on principles or rules increases the importance of the arguments presented in the SEC study, that the best solution is not necessarily if you choose one model or another. The solution can be an intermediate system, which objectively addresses the intrinsic function of Accounting, clarifying the economic-financial situation of the company, increasing the predictive condition on the part of the user ${ }^{35}$.

The reflection on the ideal accounting model to be adopted by a country is not limited to an analysis of accounting issues, but it is a matter of examining the needs of its various users, especially as regards the conflict of interests between these actors and can result in corrupt acts of accounting fraud. Anticipating the premise adopted in the next chapter, an important guiding aspect of the understanding of the postulated thesis, rule-based norms based on principles are presented as an ideal model, since both have inconsistencies that directly affect the qualitative characteristics of the information financial institutions.

\section{Fraud as a Result of the Systemic Fissure of Accounting Normative Models}

It is a peaceful position in accounting doctrine regarding the susceptibility of fraud in accounting entries that, under certain conditions, can be favoured. Among the existing variables considered by science, the systemic flaw created

\footnotetext{
${ }^{33} \operatorname{Lima}(2014)$.

${ }^{34}$ Shields (2006).

${ }^{35}$ Dantas, Rodrigues, Niyama \& Mendes (2010) at 25.
} 
by accounting standardisation, and which provides an uncountable number of possible manipulations of the records and accounting information, is the object of investigation of the present study.

Fraud perpetrated through the manipulation of records and accounting and financial information for the purpose of diverting resources and providing personal gains of an illicit nature starts with the introduction in the accounting literature of the term "creative accounting" to refer to exploiting the flaws and weaknesses of accounting standards which enable the presentation of financial statements that reflect the desired image, but which do not necessarily correspond to what it would actually be ${ }^{36}$.

Virtually all conceptions that seek to define creative accounting consider the opportunity generated by gaps in accounting standards as a constituent element of their conceptual structure, i.e., the process of constructing accounting standardisation is a significant factor for the creation of possibilities of fraud, since the simulation of accounting facts with real appearance uses the weaknesses of accounting standards, whether by legal voids, high degree of subjectivity, incompleteness, among others.

It should be noted that the recognition given by the accounting doctrine about fraud under the mantle of creative accounting is imprudent and inadequate, since it masks the shadowy element behind the opportunistic and manipulative technique of certain users of accounting, giving them a denomination that mitigates its seriousness, that is, corruption. In the same sense, José Juan Blasco Lang $^{37}$ adds:

The term creative accounting has been introduced in the accounting literature to describe the process by which knowledge of accounting standards is used to manipulate accounting statement figures and is in fact a euphemism used to avoid referring to these practices by their real names, devices accounting, manipulation or accounting fraud.

Thus, it must be said that the use of the term creative accounting to refer to accounting fraud is inadequate, since they have differences of a finalistic nature. The creative accounting also can be seen as the process of carefully managing the gaps in accounting standards, admitted in a context of flexibility and omission of the standards themselves, consciously influencing the financial position within the limits of the rules of the game, without any purpose of misappropriation of assets. On the other hand, accounting fraud consists of the intentional act or omission of those responsible for the preparation of accounting information, outside the legal framework, inducing recipients to error to sponsor misappropriation of assets ${ }^{38}$.

Accounting fraud is an important upholder of corruption as it is an indispensable tool for masking illicit transactions and hiding the origin and the real destination of financial amounts. In this way, money laundering from

\footnotetext{
${ }^{36}$ Lainez \& Callao (1999).

${ }^{37}$ Lang (1998) at 10.

${ }^{38}$ Santos \& Grateron (2003).
} 
corrupt activities cannot succeed without the essential support of fraudulent accounting techniques that take advantage of normative loopholes to produce opportunistic interpretations with the aim of conferring an appearance of legality to illicit activities.

More recently, Brazilian legislation timidly recognised the role of accounting fraud in sustaining corrupt activities, through Federal Decree No. 8.420/2015, which regulates Act No. 12.846/2013, known as the Corporate Anti-Corruption Law, which, in item VI of article 42 , imposes the accuracy and completeness of transactions in the corporate records as one of the parameters for verifying the effectiveness of anti-corruption integrity programs.

The flexibility of accounting standards can be associated with the creation of situations that allow the occurrence of typical facts of creative accounting, which, in the best of words, result in fraud, since, in the last analysis, they are nothing more than opportunities for ethical deviations from to hide illicit activities such as money laundering from bribery of public agents, financing of terrorism, tax evasion and avoidance, among other crimes.

As an alternative to prophylactic creative accounting, the ethical regulation of the accounting activity performed by accountants and auditors, with the main objective of preventing the accounting operators from being seduced by the facility and impunity on practicing of corrupt conduct:

To this must be added the own flexibility present in accounting standards, more in some countries than in others, which allows to use several criteria to account for the same economic fact. In this context, the so-called "creative accounting" arises, which is part of the intentionality of companies to take advantage of the existence of subjectivity, existing alternatives and the vague regulation of some accounting aspects in order to obtain financial statements that represent the desired image ${ }^{39}$.

This paper disagrees with the above-mentioned proposal, since legal doctrine has already established a solid understanding in the sense that ethical sanctions per se are not enough to curb corrupt conduct by not being able to independently achieve so many elements that influence choice of individuals. The rational choice theory provides the basis of this thought by establishing that an individual profile guided by the concept of rent-seeking, according to which, people are guided by a teleological rationality linked to the maximisation of the most effective means to achieve their purposes in function of their own interests $^{40}$. In other words, individuals, as rational beings, in the quest for selfinterest, decide for corrupt practice after a valuation of the costs and benefits of the activity, performing it when the benefits outweigh the costs of accomplishing it.

Obviously, formulated rational judgments have a subjectivity charge that makes them legitimately unstable, since the cost-benefit assessment of illicit conduct will vary according to each individual with his or her own biography associated with the encompassing context in which it is found. However, the

\footnotetext{
${ }^{39}$ Kraemer (2004) at 10.

${ }^{40}$ Gomes (2014).
} 
doctrine provides common elements that influence the decision-making process of rational individuals in relation to corrupt behaviour, and there are several theoretical models that translate said decision-making process into an equational mathematical structure, such as the Becker model ${ }^{41}$, and the latest Olken \& Pande model ${ }^{42}$ that is transcribed below:

$$
w-v<\frac{1-p}{p}(b-d)
$$

This model gathers the different options that influence the decision making of individuals. It follows from the premise that the individual has an income of any nature, and can be a salary, for example, represented by (w). In considering the possibility of fraudulent conduct, the person takes into account the probability of being discovered (p) and, as a consequence, suffer an undesirable consequence on his or her primary/official source of income, such as, for example, dismissal from office occupy, and perceive another lower income, or moral ostracism, conceived as an external option (v). However, it is also considered that the conduct can be successful, going unnoticed and receiving the proceeds of illicit activity (b), such as bribery, subtracting the costs inherent to the corrupt practice (d), such as the silence of third parties, the payment of employees, money laundering, among others.

The model proposal is to provide an initial probability parameter for the occurrence of fraudulent conduct and is very prone to corruption when the product of the difference between the income (w) and the external options (v) is less than the net proceeds of the corrupt activity that are (b) subtracted their costs (d) and multiplied by the probability of detection (p).

What is meant by this reflexive process is to demonstrate that there are as many other factors as the moral ethics that make up the set of options that the individual takes into account when deciding to carry out a fraudulent conduct. Professional regulations with ethical content contribute to the weight of the "external option" variable, however, studies show that sanctioning content standards on freedoms and property have a greater disincentive impact on unwanted conducts.

In this sense, Calabresi \& Melamedi ${ }^{43}$ proposes a classification of the sanctioning norms that, duly adopted, create disincentive costs of conduct, that is, the norms of responsibility and inalienability. The liability rules impose a penalty equal to the amount of damage caused by an unlawful act, seeking to restore the previous patrimonial situation of the subject whose right was violated, and which in the legal order is supported by the theory of civil liability inserted in article 5, item X, of the Federal Constitution, and in article 186 of the Civil Code. The norms of inalienability and reserve to the assets of life to which society confers a maximum and unquestionable value that needs greater protection,

\footnotetext{
${ }^{41}$ Becker (1968).

${ }^{42}$ Olken \& Pande (2012).

${ }^{43}$ Calabresi \& Malamedi (1972).
} 
culminating sanctions higher than the expected benefit of the potential offender with the objective of punishing and, at the same time, discouraging the conduct, characterised in the criminal norms of the Brazilian legal system.

In Brazil there are a number of normative sources that seek to combat accounting fraud, such as the codes of ethics of voluntary adherence, such as the Code of Ethics of the Professional Accountant, approved by Resolution No. 803/1996 of the Federal Accounting Council. The Brazilian Accounting Standards and the Accounting Principles are other administrative standards, issued by the Federal Accounting Council, which aim to guide accounting activity towards ethical standards of subjectivity control.

In addition, there are administrative organs of internal and external control that seek to ensure compliance with ethical standards of accounting and to restrain, although not specifically, accounting fraud by means of manipulation of entries and records. The capital market has a more aggressive control than the rest of the Brazilian private sector, since this sector of the economy has the Securities and Exchange Commission (CVM), an autonomous entity in special regime, linked to the Ministry of Finance, with administrative authority independence, lack of subordination, stability of its directors and financial and budgetary autonomy, to exercise effective control over the professional activities of this specific market, especially with regard to the control of accounting information and auditing of publicly-held companies, in order to provide greater security to its users, as is clear from articles 1 and 2 of the Act No. 6.386/1976.

In the public sphere, the internal control of accounting activities in Public Administration is exercised by the Audit and Controlling Courts of the Union, States and Municipalities, within the scope of executive power, exercising an audit role of public accounts, having as legal basis the article 70 of the Federal Constitution, which explains how the internal control of the Legislative, Executive and Judiciary Powers should operate and establishes the accountability mechanism. This control extends, at federal level, to municipalities and public foundations, based on article 5 of SFC/MF No. 2, of December 20, 2000. External control is a function conferred by article 71 of the Federal Constitution to the Powers Legislative, being of competence of the National Congress at the federal level, of the Legislative Assemblies in the States, of the Legislative Chamber of the Federal District and of the Municipal Councils in the Municipalities.

However, Brazil is slowly moving towards legal-criminal responses against accounting fraud, because even after a series of scandals involving Brazilian companies and falsification of accounting entries, it has not yet been enough for national legislators to criminalise with specific criminal type accounting fraud and to protect the trust and good faith of private relations as a legal right to be protected by criminal law. The 2001 corporate insolvency scandal of Enron, one of the largest energy companies in the world, due to the accounting manipulation of the company's public statements that resulted in a $\$ 22$ billion debt and the bankruptcy was enough to create chaos over the US economy and culminate in the Sarbanes-Oxley Act (SOX), which, among other provisions, provides for a series of criminal sanctions for acts of forgery, alteration or 
destruction of accounting documents and frauds against shareholders and creditors with false information, in addition to the objective liability of the legal entity.

The most recent and most notorious case in Brazil was the accounting fraud operated by Banco PanAmericano, discovered by the Central Bank in a special inspection focused on credit assignment, in 2010, when it was discovered that a breach of more than 5 billion of Brazilian currency which was masked by duplicity of credit portfolios in the financial institution's balance sheets.

Even though Brazil has not taken any legislative measures of a criminal nature to combat accounting fraud, which is momentarily punished as a crime of tax evasion when it reaches the treasury and with administrative fines imposed by the regulatory authorities, such as the Central Bank, it is notable the national inattention regarding the gaps caused by accounting standardisation that, besides constituting a significant factor in the (dis)advantaging of accounting fraud, has less bureaucratic-procedural obstacles to its reform compared to the federal legislation.

The recognition of the indispensable consideration of accounting normalisation in the debates about accounting fraud is endorsed by the doctrine, as clarified by Maria Kraemer by associating the normative gap as a factor intrinsically related to creative accounting:

Creative accounting practices are one of the most controversial topics today. The expression "creative accounting" has been part of the accounting language, causing a great impact in the economic, financial and managerial areas. The phenomenon of creative accounting has been the result of the flexibility of certain accounting standards, which facilitates the manipulation, misleading and misrepresentation of information ${ }^{44}$.

Although the author states that the flexibility of accounting standards as a causal factor of accounting fraud through the manipulation and falsification of accounting records, it should be emphasised that rules-based rules, which, by their nature, confer a specificity or completeness to the rules, against flexibility, can also stimulate accounting fraud by diverting its interpretation and application. In this way, accounting fraud goes far beyond manipulating the degrees of freedom allowed by the rules, but generally consists of the process by which accountants use their in-depth knowledge of accounting standards to manipulate unduly the accounts included in the accounts of company ${ }^{45}$, either because of the flexibility of principles-based standards or because of the over-specificity of rules based on rules.

Accounting standardisation can unequivocally be a facilitator for fraud, which is why it is urgent to establish a model that makes such a corrupt activity more difficult to practice and at the same time increases the likelihood of fraud detection by weighing the propensity to corruption to the right axis, thereby focusing positively on the decision of the potentially corrupt individual in the sense of influencing him not to carry out the fraudulent practice.

\footnotetext{
${ }^{44}$ Kraemer (2004) at 10.

${ }^{45}$ Amat, Moya \& Blake (1997).
} 
The above-mentioned doctrinal analysis points to an increase in the flexibility of accounting standards when they are guided by principles, as the current Brazilian standardisation guides, in the wake of the International Accounting Standards Board, since the material content open to a greater margin of interpretation while at the same time eliminating the overlapping of norms, it also leads to a scenario of imprecision due to the coexistence of a multiplicity of possible readings, among which tendentious appreciations arise for the purposes of misrepresentation, often departing from the coercive pressure of corrupt executives on accounting professionals, especially when there is a relationship characterised by the vulnerability of the accountant or auditor vis-à-vis the manager.

In the same sense, the principles-based international accounting standards may create opportunity for accounting fraud:

[...] the IASB decided on accounting normalisation based essentially on principles and not rules, understanding that this would provide better quality of information to users and second, that most accountants are ethical, honest and well trained and have to make judgments and estimates that lead to a better picture of the entity's financial position.

On the other hand, since accounting policies and standards cannot cover all aspects of business transactions, there is considerable scope for entities to use alternatives, interpretations, judgments and estimates in the measurement of assets and liabilities, and in some cases, the very subjectivity and complexity of standards contributes to the use of "good accounting" harmful practices known as creative accounting or results management ${ }^{46}$.

On the other hand, the return to the old system of rules-based accounting norms also does not eliminate the potential of accounting fraud, since the greater specificity of the rules creates barriers to comparability and consequent misconception of fairness between businesses, creating excessive controls for some too slow for others, which in certain situations can create timely scenarios for fraud. The inherent exhaustiveness of the rules can also transgress the true purposes of accounting, since it does not assume optimising warrants, which end up leaving the accounting entries under the mantle of a superficial conformity, when this does not lead to the complexity of the rules in view of the excess of watertight determinations that enable financial engineering intelligences to circumvent these rules in a sophisticated way.

Such flaws that accompany normative approaches to accounting, also called normative gaps, that create timely contexts for accounting fraud practice, consist of true systemic fissures, since when the normative system that regulates accounting activity alone is not capable of to curb fraudulent activities and still generates the opportunism or permissibility for such conduct, to face an imperfection that affects the entire regimental set. No norm within a normative complex has an autonomous existence, but it coexists with interdependence with the other norms that compose this system, and therefore, the failure of one

\footnotetext{
${ }^{46}$ Niyama, Rodrigues \& Rodrigues (2015) at 84.
} 
norm results in the affectation of all others, making the whole regulatory system weak and questionable.

A robust and sound accounting standard system, coupled with the effective application of appropriately proportionate sanctions and asset recovery, accurately complements the probability of detecting accounting fraud and makes external options unsatisfactory, respectively, thus discouraging predilection for the practice of the illicit act. In other words, when normative weaknesses are eliminated, making it difficult to practice accounting fraud, their probability of identification is increased, which in turn interferes with the rational process of individual choice through the exercise of corrupt activity, in order to raise their costs in relation to its benefits, thus making fraudulent behaviour discouraging in view of the high degree of risk.

Given the duality of positive and negative aspects of the principles and rules approaches and the susceptibility of these to the practice of fraud, the normative accounting by objectives can overcome the eliminatory logic between the principles based on principles or rules and brings a perspective of conjugation of both approaches within the concept of objectives, considering that the best solution is not necessarily in the choice of a model or another, but in the option of an intermediary system, which observes the primary purpose of accounting, which is the clarification of the economic-financial situation of the company and the amplification of the predictive condition by its users ${ }^{47}$.

The goal-oriented accounting normative system addresses the shortcomings of both the rules-based model and the principles-based model, because of its consistently established detailing structure with sufficient detail that does not compromise the effectiveness of standards. This picture is visible in eliminating the use of percentage tests characteristic of detailed rules and in overcoming the lack of operational guidance regarding the demand for accounting judgments without the availability of sufficient structure for such judgments.

Thus, it is concluded that proper accounting standardisation per se is not sufficient to effectively combat accounting fraud without due observation of the other aspects that influence the rational decision of individuals in relation to corrupt conduct, however, accounting standardisation is conditio sine qua non in the set of strategies that impact the variables of the individual decision making process, which justifies the importance of their understanding and correct application.

\section{Conclusion}

This study has the purpose of verifying the possibility of occurrence of fraud due to breaches in accounting standards. According to the analysis implemented, it was evidenced that both rule-based and rule-based accounting standards have weaknesses that favour accounting fraud, demonstrating that the process of replacing the rules-based model with the principles-based model did

\footnotetext{
${ }^{47}$ Dantas, Rodrigues, Niyama \& Mendes (2010).
} 
not mean a progress positive in the fight against fraud, the most ideal model being the North American based on objectives.

It is important to note that, although accounting fraud does not receive the same attention as other types of corrupt activities such as bribery, it is equally relevant in the fight against corruption, since most of it is an activity to support the success of corruption. Because of this scant attention to accounting fraud in Brazilian expertise literature, accounting fraud is constantly confused with creative accounting that consists of better manipulation of accounting records to reflect better results for companies within the limits of legality, while accounting fraud simulates a better image of the company that does not reflect reality and creates an illusory appearance of stability over time.

What differentiates an accounting fraud for the graphical movement and the possibility of making use of a cutting-edge tool and interfering in the information of the users of the characteristic accounting information of the first time, while the latter does not prejudice or prevent its users to enjoy its benefits.

There is a fine line between creative accounting and accounting fraud that can deprive the character of a technique for the lawful manipulation of accounting standards to reflect a better corporate appearance on the market and attract investors and become a tool that distorts standards and code of professional ethics to mask illicit activities and mislead users of financial information.

Accounting fraud is a corrupt practice that is harmful not only to the recipients of accounting information, but to the market as a whole, as it is capable of degenerating social values and creating a culture of impunity. For this reason, it is necessary, as one of the measures to combat accounting fraud, to uniform accounting standards to create barriers to the manipulation of regulatory loopholes to commit fraudulent actions.

\section{Bibliography}

Alencar, M.F.C.R. (2006). 'O sistema jurídico: normas, regras e princípios'. In Revista Jus Navigandi 11:1110-1111.

Available at http://www.egov.ufsc.br/portal/sites/default/files/anexos/15037-150 38-1-PB.pdf.

Alexander, D. \& E. Jermakowicz (2006). 'A true and fair view of the principles rules debate' in Abacus 42:132-164.

Amat Salas, O., Moya, S. \& J. Blake (1997). 'La contabilidad creativa' in Partida Doble 79: 24-32.

Antunes, M.T.P., Grecco, M.C.P., Formigoni, H. \& O.R.M. Neto (2012). ‘A adoção no Brasil das normas internacionais de contabilidade IFRS: o processo e seus impactos na qualidade da informação contábil' in Revista de Economia \& Relações Internacionais 20:5-19.

Becker, G.S. (1968). 'Crime and punishment: an economic approach' in The Journal of Political Economy 76:169-217.

Benston, G. J., Bromwich, M. \& A. Wagenhofer (2006). 'Principles versus rules-based accounting standards: the FASB's standard setting strategy' in Abacus 42:165188. 
Calabresi, G. \& D. Malamed (1972). 'Reglas de la propiedad, reglas de la responsabilidad e inalienabilidad: un vistazo a la Catedral' in Harvard Law Review 85:1089-1128.

Crepaldi, S.A. (1995). Curso básico de contabilidade. São Paulo: Editora Atlas.

D’Amore, D. \& A.S. Castro (1976). Contabilidade geral. São Paulo: Editora Brasiliense.

Dantas, J.A., Rodrigues, F.F., Niyama, J.K. \& P.C.M. Mendes (2010). 'Normatização contábil baseada em princípios ou em regras? Benefícios, custos, oportunidades e riscos' in Revista de Contabilidade e Organizações - FEA-RP/USP 4:3-29.

Franco, H. (1997). Contabilidade geral. 23rd ed. São Paulo: Editora Atlas.

Gomes, J.V.L. (2014). 'O cidadão frente à corrupção: o associativismo é a fonte de cultura política e ação coletiva?' Paper presented at the annual meeting for the Associação Brasileira de Ciência Política, Aug. 1-4, Gramado, Brazil.

Gil, A.C. (2008). Métodos e técnicas de pesquisa social. 6th ed. São Paulo: Editora Atlas.

Günter, H. (2006). 'Pesquisa qualitativa versus pesquisa quantitativa: está é a questão?' in Psicologia: Teoria e Pesquisa 22:201-210.

Hendriksen, E.S. \& M.F. Van Breda (1999). Teoria da contabilidade. São Paulo: Editora Atlas.

Jreige, E.F. (1998). 'True and fair view: um entrave ou um impulso para a contabilidade?' in Caderno de Estudos FIPECAFI 10:35-46.

Kothari, S.P. (2001). 'Capital markets research in accounting' in Journal of Accounting and Economics 31:105-231.

Kraemer, M. (2004). 'Contabilidade criativa maquiando as demonstrações contábeis' in Pensar Contábil 28:1-13.

Lainez, J.A. \& S. Callao (1999). Contabilidad creativa. Madrid: Cívitas Ediciones.

Lang, J.J.B. (1998). 'De la contabilidad creativa al delito contable' in Partida Doble $85: 33-39$.

Lima, A. C. F. (2014) 'A teoria dos princípios de Robert Alexy'. Revista Jus Navigandi 19(4078). Available at https://jus.com.br/artigos/31472/a-teoria-dos-principiosde-robert-alexy.

Nelson, M.W. Elliott, J. \& R.L. Tarpley (2002). 'Evidence from auditors about manager's and auditor's earnings management decisions' in The Accounting Review 77:175202.

Nelson, M.W. Elliott, J. \& R.L. Tarpley (2003). 'Behavioral evidence on the effects of principles and rules-based standards' in Accounting Horizons 17:91-104.

Niyama, K.J.. Rodrigues, A.M.G. \& J.M. Rodrigues (2015). 'Algumas reflexões sobre contabilidade criativa e as normas internacionais de contabilidade' in Revista Universo Contábil 11:69-87.

Noble, H.S. (1956). Princípios de contabilidade. Rio de Janeiro: W. M. Jackson Inc. Rio.

Olken, B.A. \& R. Pande (2012). 'Corruption in development countries' in Annual Review of Economics 4:479-509.

Paulo, E., Carvalho, L.N.G. \& L.F.A.P. Girão (2014). 'Algumas questões sobre a normatização contábil baseada em princípios, regras e objetivos' in Revista Evidenciação Contábil \& Financeira 2:24-39.

Santos, A. \& I.R.G. Grateron (2003). 'Contabilidade criativa e responsabilidade dos auditores' in Revista Contabilidade \& Finanças 32:7-22.

Schipper, K. (2003). 'Principles-based accounting standards' in Accounting Horizons 17:61-72.

Shields, H. (2006). Principles not rules: a question of judgement. Edinburgh: The Institute of Chartered Accountants of Scotland. 
Vol. 5, No. 3 Godoi \& Dias: Accounting Standardisation, Systemic Fissure...

Wustemann, J. \& S. Wustemann (2010). 'Why consistency of accounting standards matters: a contribution to the rules-versus-principles debate in financial reporting' in Abacus 46:1-27. 